\title{
Mistyczne znaczenie ognia
}

\author{
Paweł Gocko \\ Chrześcijańska Akademia Teologiczna w Warszawie \\ Polska \\ pavlogoc@gmail.com
}

Paweł Gocko, The mystical meaning of Fire, Elpis, 19 2017: 9-13.

\begin{abstract}
Fire is one of the elements of nature and phenomenon of the world, through which God reveals his power before human. It is very important phenomenon in every culture and religion where fire is an object of worship and mystical contact with God. Fire especially reveals in Christianity and contains a lot of symbols which examples we found in the Holy Bible. Its presence and meaning in Christianity is demonstrating every year by descent of Holy Fire in the Holy Sculpture in Jerusalem. It is a symbol of grace and life with God in Holy Spirit. Fire will be present also in the end times as an object of destruction and condemnation for the world and sinners. Undoubtedly, fire is present in every reality and as symbol of life and death is a warning sign for human about his future and relationship with God. Fire is the mystical sign of contact and unity of God and man.

Streszczenie: Ogień jest jednym z żywiołów i zjawisk otaczającego świata, poprzez który Bóg objawia człowiekowi Swą moc. We wszystkich kulturach i religiach stanowi ważne zjawisko, które jest przedmiotem kultu i mistycznego kontaktu z Bogiem. W sposób szczególny przejawia się w chrześcijaństwie i posiada wiele symboli, na co przykłady znajdujemy w licznych cytatach z Pisma Świętego. Jego obecność i znaczenie w chrześcijaństwie podkreśla coroczne zstąpienie Świętego Ognia w Grobie Pańskim w Jerozolimie, które jest symbolem Bożej łaski i życia w Duchu Świętym. Ogień będzie obecny także w czasach ostatecznych, jako przedmiot zagłady świata i potępienia grzeszników. Niewątpliwie ogień jest zatem obecny w każdej rzeczywistości i jako symbol życia i śmierci jest dla człowieka znakiem ostrzegawczym o jego przyszłości i relacjach z Bogiem. Ogień jest mistycznym znakiem kontaktu i jedności człowieka z Bogiem.
\end{abstract}

Keywords: fire, mysticism, Holy Fire, Holy Bible, Christianity

Słowa kluczowe: ogień, mistycyzm, Święty Ogień, Pismo Święte, chrześcijaństwo

\section{Wstęp}

Bóg objawia się człowiekowi na różne sposoby. W sposób mistyczny daje się On poznać poprzez wiele różnych zjawisk w otaczającym nas świecie, który stworzył. Mistycyzm stanowi bowiem poszukiwanie możliwie najbardziej bezpośredniego doświadczenia Boga lub życia, którego celem jest zjednoczenie z Bogiem ${ }^{1}$. Ogień jest zaś jednym z owych zjawisk otaczającego świata, poprzez które człowiek może w mistyczny sposób doświadczyć obecności Boga i działania Bożego.

Ogień jest zjawiskiem, które fascynowało człowieka od najwcześniejszych lat istnienia życia na Ziemi. Stał się jednym $\mathrm{z}$ fundamentalnych wynalazków okresu prehistorycznego ludzkości. Z fizycznego punktu widzenia ogień jest właściwie nie tyle jednolitym zjawiskiem, co koincydencją różnych fizykochemicznych zjawisk. Stanowi emisję bardzo ważnych elementów oddziaływujących na zmysły człowieka: światła, ciepła i dźwięku. Dlatego też wpłynął on tak znacząco na rozwój cywilizacyjny i na człowieka, który po swoim upadku, doświadczając trudów życia, przywiązał się do niego jako do światła, które rozjaśni mrok i ciepła, które ogrzeje go podczas chłodu. Bóg po upadku człowieka nie zostawił go do końca samemu sobie, lecz dał mu również naturalne źródło światła

E. Underhill, The Essentials of Mysticism, Nowy Jork 1960, s. 21. i ciepła, z którego nauczył się on korzystać. To światło, ciepło i dźwięk, które objawiają się w ogniu, stanowią mistyczne energie Boże, poprzez które możemy Go doświadczyć.

W różnych kulturach i epokach ogień miał przypisanych wiele różnych znaczeń symbolicznych ${ }^{2}$. W wielu filozofiach i religiach był np. symbolem życia, oczyszczenia i energii witalnej, jednakże w związku z tym, że był także przyczyną katastrofalnych pożarów i śmierci, był także symbolem gwałtowności i wzbudzał grozę.

\section{Znaczenie ognia w Starym Testamencie}

Stary Testament ukazuje nam wiele przykładów znaczenia ognia dla człowieka, a także w relacjach między człowiekiem i Bogiem. Według św. Grzegorza z Nyssy ogień jest tożsamy ze światłem, które pojawiło się jako

\footnotetext{
2 Te symboliczne znaczenia niewątpliwie miały podłoże filozoficzno-religijne i mistyczne. Wg mitologii greckiej Prometeusz zdobył ogień dla ludzkości, kradnąc go bogom. Od dawna przypisywano zatem zjawisku ognia boskie i mistyczne pochodzenie. Heraklit z Efezu natomiast okre-

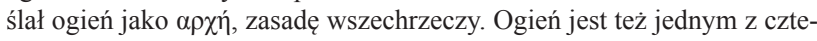
rech żywiołów i składników świata w koncepcji Empedoklesa, rozwiniętej później przez Arystotelesa (za: W. Tatarkiewicz, Historia filozofii, t. I, Warszawa 2007, ss. 19, 25)
} 
pierwsze w procesie stworzenia świata: Geneza materii podą̇a za konkretnym cyklem i określonym porzadkiem. Najpierw pojawia się ogień, oddzielajacy się nagle z głębi nieuformowanej substancji i oświetlający wszystko swoim blaskiem: „I stała się świattość!’’’.

Ogień jest energią, dzięki której człowiek składa dziękczynną lub przebłagalną ofiarę dla Pana. Kain i Abel prawdopodobnie po raz pierwszy złożyli Bogu ofiarę całopalną. Podobnie też Noe po wyjściu z arki zbudowat ottarz dla Pana i wziawszy ze wszystkich zwierzat czystych i z ptaków czystych złożyt je w ofierze calopalnej na tym ołtarzu $(\mathrm{Rdz} 8,20)$. Ofiara całopalna była miła Bogu, ponieważ wydzielała , mita woń”. Dlatego też Pan obiecał: Nie będę już więcej złorzeczyt ziemi ze względu na ludzi, bo usposobienie czlowieka jest złe już od młodości. Przeto już nigdy nie zgładze wszystkiego, co żyje, jak to uczynitem $(\operatorname{Rdz} 8,21)$. Ogień biorący udział w ofierze całopalnej jest zatem symbolem przymierza Boga z człowiekiem. Pojawia się on również podczas zawarcia przymierza Boga z Abrahamem: A kiedy stońce zaszlo i nastat mrok nieprzenikniony, ukazat się dym jakby wydobywajacy się z pieca i ogień niby gorejaca pochodnia i przesunęty sie między połowami zwierzat. Wtedy to właśnie Pan zawart przymierze z Abramem (Rdz 15, 17-18). Ogień po raz pierwszy staje się także narzędziem kary Bożej: Wtedy Pan spuścit na Sodome i Gomorę deszcz siarki i ognia (Rdz 19, 24).

Księga Wyjścia w sposób szczególny ukazuje nam przebóstwiony charakter ognia jako zjawisko, pod którym sam Bóg objawia się człowiekowi. Mojżesz po raz pierwszy spotkał Boga pod postacią gorejącego krzewu: Wtem ukazat mu się aniot Pański w ptomieniu ognia ze środka krzewu; i spojrzat, a oto krzew plonat ogniem, jednakże krzew nie sptonat (Wj 3,2). Po wyjściu Izraelitów z ziemi egipskiej Bóg ukazywał swemu ludowi drogę nocą jako słup ognia (Wj 40, 38). Ogień był znakiem obecności Boga i okrywał pierwszą świątynię Boga - Namiot Zgromadzenia: $W$ dniu, kiedy ustawiono przybytek, okrył go wraz z Namiotem Świadectwa obłok $i$ od wieczora aż do rana pozostawat nad przybytkiem na ksztalt ognia. I tak działo się zawsze: obłok okrywat go w dzień, a w nocy - jakby blask ognia (Lb 9, 15-16). Później sam Bóg zostaje w końcu porównany do ognia: Gdyż Pan, Bóg twój, jest ogniem trawiacym (Pwt 4, 24). Prorok Jeremiasz porównuje także Słowo Boże do ognia (Jer 23, 29). Trzej młodzieńcy w niewoli babilońskiej zostali wrzuceni do potężnego ognia, który nie wyrządził im żadnej krzywdy i stał się źródłem chwały Boga Izraela (Dn 3,1-97). Towarzyszy także potężnemu Majestatowi Boskiemu, o czym pisze Prorok Daniel: Patrzyłem, aż postawiono trony, a Przedwieczny zajat miejsce. (...) Tron Jego byt z ognistych ptomieni, jego koła - plonacy ogień. Strumień ognia się rozlewat $i$ wyptywat od Niego (Dn 7, 9-10). Poświęcenie Świątyni Jerozolimskiej miało miejsce za pośrednictwem błogosławieństwa ognia zstępującego z nieba: A gdy Salomon zakończyt modlitwę,

G. Fłorowskij, Восточные отиы IV века, Paryż 1931, s. 169. spadt ogień z niebios $i$ strawit ofiare całopalna i ofiary rzeźne... (2 Krn 7, 1). Podobne błogosławieństwo ognia miało miejsce na Górze Karmel, aby uświęcić ofiarę proroka Eliasza i nawrócić lud Izraela, który oddawał się bałwochwalstwu (1 Krl 18, 19-40). Powtórne poświęcenie Świątyni w 164 r. p. n. e., po jej zbezczeszczeniu przez pogan, zapoczątkowało także słynne żydowskie święto Świateł - Chanukę (1 Mch 4, 56-59), zwane także świętem ognia: Mając obchodzić Oczyszczenie Światyni dwudziestego piatego Kislew, uważaliśmy, że trzeba wam o tym donieść, abyście wy także obchodzili Święto Namiotów i ognia na pamiatkę tego, jak Nehemiasz odbudowat Światynię i Ottarz, a potem złożyt ofiary (2 Mch $1,18)$.

Ogień w Starym Testamencie miał znaczenie Boskie, mistyczne i oczyszczające. Ofiara całopalna była bowiem oczyszczana przez ogień i wraz z dymem wznosi się ku niebu do Boga. Podobnego i pełniejszego znaczenia nabiera on także po wcieleniu Słowa Bożego.

\section{Znaczenie ognia w Nowym Testamencie}

Św. Jan Chrzciciel mówi o sobie: Ja chrzczę woda, natomiast o Jezusie Chrystusie: On chrzcić was będzie Duchem Świętym i ogniem (Łk 3, 16). Sam Chrystus mówi zaś następująco: Ogień przyszedtem rzucić na ziemię i jakżebym pragnat, aby już ptonąt (Łk 12, 49). Ogień jest tutaj rozumiany w sposób wieloznaczny: jako ogień wiary, nadziei i miłości, który ogarnął ludzkość, ogień symbolizujący wojnę i niezgodę między narodami ${ }^{4}$, Ducha Świętego, który w dniu Pięćdziesiątnicy ogarnął Apostołów pod postacią ognia, a także jako Święty Ogień dla prawosławnych chrześcijan, który w cudowny sposób corocznie w Wielką Sobotę pojawia się w Bazylice Grobu Pańskiego w Jerozolimie. Święty Ogień pojawia się nieprzerwanie od IV w. ${ }^{5}$, choć i wcześniej miejsce Grobu Pańskiego wyróżniało się niespotykanym, cudownym światłem. Jak pisze św. Grzegorz z Nyssy: „Piotr wierzył, widział nie tylko oczami cielesnymi, lecz również wielkim rozumem apostolskim, że Grób przepełniony jest światłem, chociaż i noc była”. Podobnie świadczy św. Jan z Damaszku: „Piotr stanąwszy przy Grobie i widząc światłość w jego wnętrzu, zatrwożył się"7. Ziemskim i wizualnym źródłem światła jest ogień, a ogień przebóstwiony jest ogniem niezwykłym.

\footnotetext{
4 W późniejszych wersetach Chrystus mówi bowiem: Czy myślicie, że przyszedtem dać ziemi pokój? Nie, powiadam wam, lecz rozłam. Odtad bowiem pięcioro będzie rozdwojonych $w$ jednym domu: troje stanie przeciwko dwojgu, a dwoje przeciw trojgu (Łk 12, 51-52). Ogień może tu także oznaczać zapowiedź późniejszego zniszczenia przez Rzymian Jerozolimy wraz ze Świątynią i początek wielkiego wygnania Izraelitów, które miały miejsce w 70 r. n. e.

5 Za: http://cudognia.pl/promowany/podstawowe-informacje-2/ (dostęp: 16.05.2016 r.).

6 Siostra Maria (Jurczuk), Ziemia Święta, Cud Ognia i Chwała Obłoków, Hajnówka 1996, s. 27.

7 Tamże.
} 
Bez wątpienia cud Świętego Ognia stanowi bardzo wymowne potwierdzenie Boskiego i mistycznego znaczenia zjawiska ognia jako Boże błogosławieństwo, które co roku spływa na wiernych chrześcijan oraz na cały świat. Ogień, który jest jaśniejszy od zwykłego ognia, który nie parzy podczas pierwszego kontaktu, stanowi unaocznienie łaski Bożej, jaka co roku uświęca nowotestamentową Paschę - Zmartwychwstanie Chrystusa. Ogień jest symbolem życia, a co więcej - staje się źródłem powrotu do życia i nieśmiertelności. Z tego względu ogień jest symbolem Boskości i łaski Świętego Ducha. Wielkie znaczenie ma $\mathrm{w}$ związku z tym ogień rozpalany w cerkwi - świece stawiane podczas nabożeństw - jako symbol modlitwy i swoisty, nowotestamentowy odpowiednik ofiary całopalnej. Podobne znaczenie, zarówno w Starym jak i Nowym Testamencie, ma także ogień tworzący dym kadzidlany w świątyni, który jest symbolem modlitwy i wiernego oddania Bogu. Jak czytamy w Księdze Psalmów: Niech moja modlitwa stale będzie przed Toba jak kadzidto; wzniesienie rak moich - jak ofiara wieczorna (Ps 140, 2). W modlitwie, którą kapłan odmawia przed kadzeniem, czytamy: Kadzidło ofiarujemy Tobie, Chryste Boże nasz, jako miła wonność duchowa, przyjawszy ja na Twój nadniebiański oltarz, ześlij nam taskę Najświętszego Twego Ducha ${ }^{8}$. Za pośrednictwem ognia prosimy zatem o łaskę Świętego Ducha, która w podobny sposób zeszła na Apostołów w Dniu Pięćdziesiątnicy - poprzez języki ognia (Dz 2, 1-4).

Ten ogień łaski, który zstąpił wówczas na Apostołów wydaje się być tym samym ogniem, który każdego roku w Wielką Sobotę schodzi na wiernych chrześcijan w Bazylice Grobu Pańskiego w Jerozolimie. Pojawia się on nie po raz pierwszy w historii świata. Ogniem Bożej łaski był także starotestamentowy ogień, który na oczach Mojżesza nie spalił krzewu i wskazywał drogę Izraelitom. Stał się nim także ogień w piecu babilońskiego króla Nabuchodonozora, z którego wyszli nietknięci trzej izraelscy młodzieńcy. Ogień łaski jest ogniem przebóstwionym, Świętym Ogniem, który charakteryzuje się tym, że nie czyni wierzącemu człowiekowi żadnej krzywdy. Co najwyżej ogrzewa i daje ciepło będące wyrazem Bożej miłości do człowieka. Święty Ogień w mistyczny sposób oświetla drogę wiernym podążającym za Chrystusem. Jest tym światłem, o którym Bóg rzekł po raz pierwszy: „Niechaj się stanie światłość!” (Rdz 1,3).

Właściwością mistycznego znaczenia ognia jest to, że może on służyć celom dobrym i przebóstwionym, ale także celom złym i nieczystym. Ogień może przynosić cierpienie. Może być zarówno źródłem dobra i ciepła, jak i źródłem nieszczęścia i cierpienia. Jest żywiołem niszczącym materię w pożarze, a także żywiołem, który jest narzędziem wiecznego potępienia - mąk w ogniu piekielnym. Jest on nazywany ogniem niegasnącym i, jak pisze św. Grzegorz Palamas, „posiada niewyczerpane źródło palenia się, a jest

\footnotetext{
8 Za: http://liturgia.cerkiew.pl/pages/File/docs/odlitwa-04-proskomidia. pdf (z dn. 15.05.2016 r.). Boska Liturgia Świętego Jana Chryzostoma, Warszawa 2001, s. 6.
}

to właśnie unaocznienie sił piekielnych"ฯ. Św. Jan Złotousty tłumaczy, iż w odróżnieniu od ognia materialnego, który spala i niszczy wszystko, co pochłonie, ogień piekielny wiecznie pali tych, którzy trafią $\mathrm{w}$ jego płomienie i nigdy nie słabnie. Dlatego też nazywany jest niegasną$\mathrm{cym}^{10}$. Św. męczennik Justyn Filozof mówi o szatanie, że wpadnie on „w ogień ze swoim wojskiem” i że ci, którzy kroczą za nim, będą męczyć się „,bez końca”"11. Z kolei św. Jan Damasceński podkreśla, iż nie jest to ogień naturalny, a jego naturę zna jedynie sam Bóg ${ }^{12}$.

Przypowieść o bogaczu i ubogim Łazarzu daje nam pewne niejasne wyobrażenie o ogniu piekielnym (Łk 16, 19-31). Dowiadujemy się w niej, iż po śmierci bogacz został pozbawiony wszystkiego, czym cieszył się za życia. Doświadcza nieznośnych cierpień, niezaspokojonego pragnienia, strachu, trwogi i nieustannych wyrzutów sumienia, których Bóg nie przyjmuje, gdyż ujawniają się dopiero po śmierci. Bogacz jednocześnie rozpacza nad tym, że ci, którymi gardził, choćby Łazarz, rozkoszują się dziś wiecznym szczęściem i błogosławieństwem. W przypowieści trudno jednoznacznie określić miejsce męki bogacza, ale można zauważyć, że to właśnie ogień jest bezpośrednią przyczyną jego cierpien. Woła on do Abrahama: Ojcze Abrahamie, ulituj się nade mna i przyślij Łazarza, aby koniec swego palca umoczył $w$ wodzie i ochłodzit mój język, bo strasznie cierpię w tym płomieniu (Łk 16, 24). Pomimo tego, że ogień trawi go w całości, to prosi jedynie o umoczony koniec palca, aby ochłodzić tylko swój język, lecz nawet to nie jest mu już dane.

O wiecznym ogniu piekielnym pisze dość dokładnie św. Nikodem Hagioryta: „Wieczne oznacza to, «co jest zawsze», co nigdy się nie kończy [...] Pamiętaj bracie mój, grzeszniku, o tej zawziętości, o tym jakim żarem uderzy w ciebie ogień gehenny. Pragnąc go przedstawić, Apostoł Paweł powiedział: jakże przerażajace jest oczekiwanie sq̨du i żar ognia, który ma trawić opornych (Hbr 10, 27). Komentując te słowa, św. Teofilakt Bułgarski mówi: «Tak jak jakieś zwierzę czymś rozdrażnione złości się i staje się bestią, tak samo ten ogień, sycony w pewien sposób gniewem i zawziętością, ma nieustannie pożerać wrogów Boga, tzn. grzeszników». Dlatego, bracie mój, postaraj się oczyścić z grzechów, których dopuściłeś się czynem, słowem, myślą. W jaki sposób? Przez pokutę, spowiedź, łzy, wypełnianie przyrzeczeń, zdobywanie cnót. Jeśli w ten sposób za życia oczyścisz się z grzechów, to ten ogień nie będzie mieć powodu, aby cię spalać. Wówczas, uwolniwszy się od niego, będziesz mógł stanąć po prawicy Sędziego razem ze wszystkimi sprawiedliwymi i usłyszeć ten błogosławiony głos, który mówi: Chodźcie, błogosławieni mojego Ojca, weźcie w posiadanie królestwo przygotowane dla was od stworzenia świata (Mt 25, 34) $)^{13}$.

\footnotetext{
Św. Grzegorz Palamas, Homilie, 59, za: N. Vasiliadis, Misterium śmierci, Białystok 2005, ss. 488-489.

10 Św. Jan Złotousty, Do Teodora, upadtego, 1. 10. [PG 47, 289].

11 N. Vasiliadis, Misterium śmierci, s. 489.

12 Św. Jan Damasceński, Tocznoje izłożenije prawosławnoj wiery, ks. IV, Moskwa 1992, s. 272

13 Św. Nikodem Hagioryta, $N \varepsilon \alpha K \lambda \imath \mu \alpha \zeta$, Konstantynopol 1844, s. 191.
} 
Można zatem dojść do wniosku, że ogień jest swego rodzaju symbolem nie tylko życia, ale i śmierci. Co więcej, ogień jest symbolem wszelkiej rzeczywistości w jakiej się znajdujemy. W Królestwie Bożym Boski ogień dobroci i miłości daje ciepło i wieczną szczęśliwość, a nawet daleko od Boga jest ogień, który jest gorący, palący i jest sprawcą wiecznych mąk. Ogień staje się tożsamy nie tylko $\mathrm{z}$ istnieniem $\mathrm{i}$ bytem, ale nawet $\mathrm{z}$ odrzuceniem przez człowieka bytu, którego źródłem jest wyłącznie Bóg. Jest zawsze znaczący i jak się okazuje od samego człowieka zależy to, co będzie dla niego oznaczał - źródło łaski, czy też źródło potępienia. Ogień jest tożsamy z samym Bogiem i ze wszelkim bytem i nawet będąc w tzw. niebycie, w dalekiej odległości od Boga, ogień jest wciąż obecną rzeczywistością, mimo, że posiada inne właściwości niż ogień przebóstwiony.

Należy pamiętać, że ogień jest żywiołem gwałtowności i wojny, a w czasach ostatecznych będzie obecny jako znacząca siła sądu Bożego nad światem. Wiele wzmianek o ogniu czytamy w Księdze Objawienia św. Jana: Siedmiu aniołów, majacych siedem trą, przygotowato się, aby zatrabić. I pierwszy zatrabit. A powstat grad i ogień - pomieszane z krwia, i spadly na ziemie. A sptonęta trzecia czesść ziemi i spłonęta trzecia część drzew, i spłonęta wszystka trawa zielona (Ap 8, 6-7). Jednocześnie ogień będzie żywiołem, którym Bóg ostatecznie unicestwi Swych wrogów: a zstapił ogień od Boga z nieba i pochtonat ich. A diabta, który ich zwodzi, wrzucono do jeziora ognia i siarki (Ap 20, 9-10). Ogień jest tu już jednoznacznie utożsamiany z symbolem śmierci - drugiej i ostatecznej: Jeśli się ktoś nie znalazł zapisany w księdze życia, zostat wrzucony do jeziora ognia (Ap 20, 15). Św. Symeon Nowy Teolog w sposób bardzo wyrazisty opisuje rolę ognia, gdy nadejdzie koniec świata: „Światło ściemnieje; spadną gwiazdy; słońce i księżyc zgasną. $Z$ wnętrza ziemi buchnie ogień i rozpełznie aż do morskich przestworzy. I tak, jak podczas potopu otworzyły się upusty niebieskie, i spłynęła woda, i stopniowo zalała całe mnóstwo ludzi, tak i teraz - rozstąpi się ziemia i z jej wnętrza wyjdzie ogień, lecz nie po trochu, ale cały od razu, i stanie się ognistą rzeką [...] Wówczas powie nam Pan Jezus Chrystus: «O nieszczęśni, ileż nauczałem was poprzez Swoich proroków, apostołów i prawie przez wszystkie sługi Swoje? A ileż to Ja Sam uświadamiałem wam i ile was uczyłem?»"14.

Św. Jan Złotousty uważał za istotne, aby nauczać o ogniu piekielnym. O tym powinniśmy również pamiętać dzisiaj, w epoce moralnego upadku, gdy wszystko dookoła dąży do odwrócenia nas od ewangelicznych przykazań. Z psychologiczną przenikliwością zauważa: „Ten, kto mówi o gehennie, będzie poza niebezpieczeństwem i uczyni swą duszę bardziej dziewiczą. Jeżeli będziesz milczeć, to czy stłumisz ogień gehenny? A czy jeśli bę-

Za: N. Vasiliadis, ss. 498-499

14 Św. Symeon Nowy Teolog, Stowo 23 i Słowo 66. 6, [w:] Tworenija, cz. 1. 2. dziesz mówić, to czy go zapalisz? Mówisz czy milczysz - ogień i tak płonie. Myśl o tym ogniu nieustannie, aby nigdy weń nie trafić". Święty podkreśla, że myśl o ogniu piekielnym czyni duszę dziewiczą i subtelną. Dusza podobna jest do wosku. Jeśli kierujemy do niej chłodne słowa, to budzimy w niej okrucieństwo i czynimy ją nieczułą. Jednak gdy zwracamy się do niej z płomienną mową, „mięknie ona”, a my niejako „pieczętujemy” na niej „obraz Królestwa" "15.

Tutaj można zauważyć jak bardzo istotny wpływ ma ogień - różnie pojmowany - na człowieka. Ogień materialny o różnej częstotliwości może go zarówno ogrzać i przynieść mu ukojenie, jak też i spalić, zadając cierpienie lub śmierć. Podobnie jest z ogniem wiary, ogniem Bożym, który może przynieść człowiekowi potępienie (jako ogień piekielny) lub łaskę (jako Święty Ogień). Do ognia porównywany jest nie tylko Bóg, ale także człowiek. Jak mówi św. Jan Złotousty: „Człowiek podnosi się jak burza i rozsypuje się jak proch, rozpala się jak ogień i usycha jak trawa"16.

\section{Podsumowanie}

Podsumowując kwestię mistycyzmu zjawiska ognia należy stwierdzić, iż niewątpliwie ogien jest zjawiskiem o wielkim znaczeniu dla człowieka i świata. Ogień jest jednym z fundamentów, na których opiera się świat. Może służyć człowiekowi w dobrych celach i na rzecz rozwoju jego cywilizacji, a zarazem stanowi także groźną siłę niszczącą, z którą człowiek podejmuje walkę. Jednakże ogień ma także głębokie znaczenie mistyczne. Jak widzimy na przykładzie nie tylko różnych opowieści mitologicznych i religijnych, ale przede wszystkim na licznych przykładach Pisma Świętego, ogień jest pośrednikiem w relacjach między Bogiem i człowiekiem. Ogień był i jest obecny w świątyniach, podczas składania ofiary Bogu oraz jako symbol czuwania i modlitwy. W sposób cudowny i mistyczny Bóg zsyła także corocznie Święty Ogień w Grobie Pańskim w Jerozolimie jako znak prawdziwości Swego Zmartwychwstania, Swego miłosierdzia, łaski wobec świata oraz Swej jedności z człowiekiem, której uosobieniem jest Bogoczłowiek Jezus Chrystus.

Ogień był, jest i będzie obecny także w czasach ostatecznych. Od samego człowieka zależy to, czy będzie on dla niego źródłem łaski - jako Święty Ogień, czy też źródłem potępienia - jako ogień piekielny. Stanowi zatem rzeczywisty symbol istnienia i niebytu - symbol życia i śmierci. Jednak najważniejszym mistycznym znaczeniem ognia jest to, iż będąc symbolem życia, chociażby pod postacią Świętego Ognia, daje człowiekowi nadzieję na zbawienie i mistyczne zjednoczenie z Bogiem.

\footnotetext{
15 Św. Jan Złotousty, Komentarz do 2 Listu do Tesaloniczan, 2, 3, 4 [PG 62. 477, 478].

16 Tenże, Biesieda na ,Obacze wsuje miatietsia wsiak czełowiek”, PG, t. 55, s. 559
} 


\section{Bibliografia}

Vasiliadis N., Misterium śmierci, Białystok 2005.

Siostra Maria (Jurczuk), Ziemia Święta, Cud Ognia i Chwała Obłoków, Hajnówka 1996.

Tatarkiewicz W., Historia filozofii, t. I, Warszawa 2007.
Underhill E., The Essentials of Mysticism, Nowy Jork 1960.

Fłorowskij G., Восточные Отиьы IV века, Paryż 1931.

Św. Serafim z Sarowa, Ogień Ducha Świętego, Kraków 2008.

Rozmiar artykułu: 0,6 arkusza wydawniczego 
ISSN 1508-7719

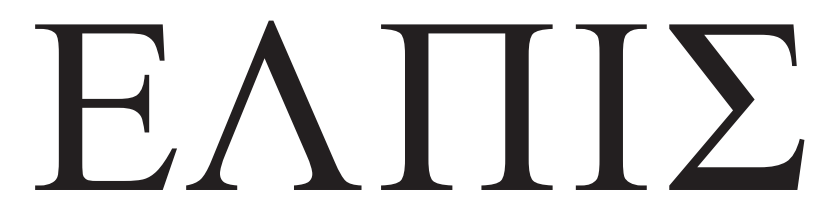

CZASOPISMO TEOLOGICZNE KATEDRY TEOLOGII PRAWOSŁAWNEJ UNIWERSYTETU W BIAŁYMSTOKU

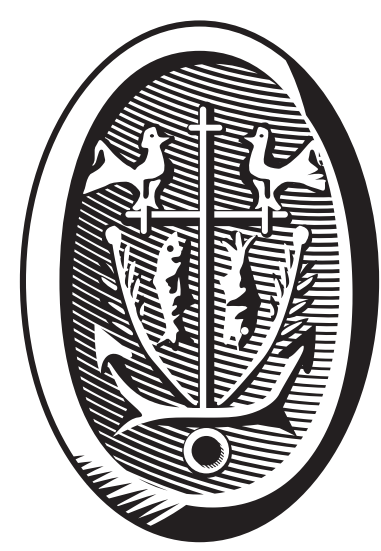

ADRES REDAKCJI

15-097 Białystok, ul. M. Skłodowskiej-Curie 14 tel. 85 745-77-80, e-mail: redakcja@elpis.edu.pl www.elpis.uwb.edu.pl 